\title{
Lintasan Belajar Teorema Pythagoras dengan Pendekatan Pendidikan Matematika Realistik
}

\author{
Ahmad Nizar Rangkuti ${ }^{1}$, Anwar Ibrahim Siregar ${ }^{2}$ \\ ${ }^{1}$ Institut Agama Islam Negeri Padangsidimpuan, Sumatera Utara \\ ${ }^{2}$ Madrasah Aliyah Bahrul Ulum Pantai Raja, Pekanbaru, Riau \\ nizarahmad1304@yahoo.com
}

\begin{abstract}
The purpose of this study was to determine the validity and practicality of the learning trajectory through a realistic approach to the subject of the Pythagorean theorem in SMP Negeri 1 Hulu Sihapas. This research is a type of validation study design research that aims to develop local instruction theory (LIT) in collaboration with researchers and educators to improve the quality of learning. This research was conducted at SMP Negeri 1 Hulu Sihapas with product trial subjects in class VIII-A, totaling 26 students. Data collection instruments used were validation sheets, questionnaires and using validity and practicality analysis techniques. The results showed that: 1) the learning trajectory through a realistic approach is said to be valid with validity 85 of the analysis of 3 validators; and 2) the learning trajectory through a realistic approach is said to be practical with a value of 85.44 from the student response questionnaire. The learning trajectory generated in this study is in the form of activities undertaken by students to achieve learning objectives, namely to understand the Pythagorean theorem concept.
\end{abstract}

Keywords: learning trajectory; the Pythagorean theorem; realistic mathematics education approach; mathematics; design research

\begin{abstract}
Abstrak
Tujuan penelitian ini adalah untuk mengetahui validitas dan praktikalitas lintasan belajar melalui pendekatan realistik pokok bahasan teorema Pythagoras di SMP Negeri 1 Hulu Sihapas. Penelitian ini merupakan penelitian design research tipe validation study yang bertujuan mengembangkan local instruction theory (LIT) dengan kerja sama antara peneliti dengan tenaga pendidik untuk meningkatkan kualitas pembelajaran. Penelitian ini dilakukan di SMP Negeri 1 Hulu Sihapas dengan subjek ujicoba produk di kelas VIII-A, berjumlah 26 siswa. Instrumen pengumpulan data yang digunakan adalah lembar validasi, angket serta menggunakan teknik analisis validitas dan praktikalitas. Hasil penelitian menunjukkan bahwa: 1) lintasan belajar melalui pendekatan realistik dikatakan valid dengan kevalidan 85 dari analisis 3 validator; dan 2) lintasan belajar melalui pendekatan realistik dikatakan praktis dengan nilai 85,44 dari angket respon siswa. Lintasan belajar yang dihasilkan pada penelitian ini berupa aktivitas-aktivitas yang dilakukan siswa untuk mencapai tujuan pembelajaran, yaitu untuk memahami konsep teorema Pythagoras.
\end{abstract}

Kata Kunci: lintasan belajar; teorema pythagoras; pendekatan pendidikan matematika realistik; matematika; design research

\footnotetext{
*Correspondence:

Email: nizarahmad1304@yahoo.com
} 


\section{PENDAHULUAN}

Pembelajaran matematika merupakan suatu bagian dari sistem pendidikan nasional yang memberikan kontribusi penting dalam pembentukan karakter siswa. Nilai-nilai karakter yang terkandung dalam matematika memiliki ciri-ciri yaitu: memiliki objek kajian abstrak, bertumpu pada kesepakatan, berpola berpikir deduktif, memiliki simbol yang kosong dari arti, dan memperhatikan semesta pembicaraan (Suherman, 2003:18). Dari hal tersebut, mata pelajaran matematika merupakan mata pelajaran yang wajib dipelajari oleh siswa. Matematika perlu dipelajari siswa karena 1) selalu digunakan dalam segi kehidupan sehari-hari; 2) semua bidang studi memerlukan matematika yang sesuai; 3) merupakan sarana komunikasi yang kuat, singkat dan jelas; 4) dapat digunakan untuk menyajikan informasi dalam berbagai cara; 5) meningkatkan kemampuan berpikir logis, ketelitian dan kesadaran keruangan, dan 6) memberi kebiasaan terhadap usaha memecahkan masalah yang menantang (Desi Syahroma, 2014:2).

Akan tetapi, kebanyakan siswa di sekolah tidak menyukai matematika karena dianggap sebagai pelajaran yang sulit untuk dipahami, sebab matematika selalu dihubungkan dengan angka dan rumus maupun dalil. Matematika menjadi pelajaran yang dirasa kurang bermakna.

Pelajaran matematika akan lebih bermakna apabila dikaitkan dalam kehidupan nyata siswa dengan ide-ide matematika. Salah satu materi matematika pada jenjang MTs/SMP sangat perlu dipahami teorema Pythagoras. Jika mengacu pada kurikulum matematika di tingkat SMP, dengan memahami materi ini akan membantu dalam pencapaian pemahaman materi berikutnya seperti materi garis singgung lingkaran, materi segiempat dan segitiga serta materi matematika lainnya. Untuk mencapai pemahaman tentang suatu materi matematika maka siswa harus memiliki kemampuan mengkomunikasikan matematika dari dunia nyata kedunia matematika atau sebaliknya. Apabila siswa mempunyai kemampuan komunikasi menandakan ia memiliki pemahaman matematika yang mendalam tentang konsep matematika yang dipelajari.

Teorema Phytagoras merupakan salah materi diantara matematika yang sering dikaitkan dengan materi matematika lainnya seperti materi bangun datar dan bangun ruang. Dengan kata lain, Teorema Phytagoras adalah teorema yang digunakan dalam menghitung luas bangun datar, yang berbunyi " Pada suatu segitiga siku siku berlaku sisi miring kuadrat sama dengan jumlah kuadrat sisi lainnya. Secara umum, jika segitiga $\mathrm{ABC}$ siku siku di $\mathrm{C}$ maka Teorema Phytagoras dapat dinyatakan $A B^{2}=A C^{2}+B C^{2}$ atau $\mathrm{c}^{2}=\mathrm{a}^{2}+\mathrm{b}^{2}$.

Teorema Pythagoras merupakan dasar untuk mengembangkan pemahaman siswa pada materi matematika lainnya, bangun datar/ruang salah satunya. Selain itu juga, materi ini sering digunakan dalam kehidupan sehari-hari seperti ilmu 
arsitek misalnya. Melihat pentingnya materi ini seharusnya pengajaran materi ini hendaknya lebih dioptimalkan.

Kenyataan menunjukkan bahwa siswa kesulitan dalam belajar teorema Pythagoras. Hal ini terlihat dari rendahnya hasil tes studi pendahuluan yang dialakukan peneliti bahwa hanya 2 orang siswa yang memperoleh nilai $\geq 70$ dari 22 siswa yang ada. Sumarto menyatakan bahwa ketika siswa diajarkan prosedur formal, mereka tidak akan mampu mengembangkan kemampuan bernalarnya tentang konep teorema Pythagoras (Sumarto \& Novilia, 2013:69-80).

Kondisi tersebut juga ditemukan saat melakukan observasi dan wawancara dengan beberapa guru di SMP Negeri 1 Hulu Sihapas. Pada saat proses pembelajaran, bahan ajar yang digunakan guru sebagai buku ajar merupakan buku teks yang disediakan di sekolah tanpa merancang sendiri bagaimana seharusnya topik teorema Pythagoras diajarkan agar memperoleh hasil belajar yang optimal. Guru menyajikan pemebelajran sesuai dengan alur yang dimuat dalam buku bukan hasil buah pikir dari guru tersebut. Akan tetapi jika dianalisis alur pembelajaran yang terdapat pada buku tidak sepenuhnya mendukung pengetahuan siswa. Materi dalam buku disajikan langsung pada konsep tanpa adanya proses melibatkan siswa dalam penemuan kosep pada materi yang dipelajari. Adapun contoh dan latihan yang disajikan hanya bertujuan untuk melatih keterampilan berhitung dan menggunakan rumus pada konsep yang sebelumnya disajikan.

Kurang relevannya isi buku dalam penekanan konsep pada saat belajar, serta rendahnya minat dan hasil belajar matematika siswa pada materi teorema pythagoras menjadi permasalahan bagi guru dalam kegiatan pembelajaran. Maka diperlukan suatu inovasi pembelajaran berupa lintasan belajar atau learning trajectory melalui berbagai pendekatan yang dapat membantu siswa dalam memahami konsep teorema Pythagoras. Melalui pendekatan tersebut siswa dapat menyelesaikan persoalan matematika yang berkaitan dengan phytagoras dan memperoleh hasil belajar yang memuaskan.

Lintasan belajar (Learning trajectory) adalah suatu desain pembelajaran yang memperhatikan tingkat berpikir siswa secara alamiah, yakni siswa belajar dengan caranya sendiri dan secara aktif membangun pengetahuannya secara terusmenerus. Learning trajectory menggambarkan pemikiran siswa melalui berbagai aktivitas untuk mencapai tujuan pembelajaran. Melalui aktivitas, siswa diajak untuk memahami konsep dan melihat makna yang terkandung dari materi yang dipelajari serta hubungannya dengan kehidupan sehari-hari. Dengan terlibatnya siswa secara aktif dalam proses pembelajaran akan mengakibatkan berkembangnya kognitif siswa secara alamiah (Slavin, 2008:45).

Dalam lintasan, tujuan pembelajaran diuraikan dalam sub-sub tujuan sedngkan proses belajar disusun berdasarkan data yang didapat dalam ruangan kelas hingga lingkungan sekolah. Jika tujuan belajar dapat dihubungkan dengan 
prosese belajar, hal ini akan mempermudah seorang guru dalam menyusun skema atau kerangka kerja untuk merancang kegiatan pembelajaran.

Untuk mendukung learning trajectory ini dibutuhkan berbagai pendekatan yang dapat memudahkan siswa dalam memahami konsep teorema Pythagoras, sehingga siswa diharapkan mampu menyelesaikan berbagai masalah matematika dengan benar dan memperoleh hasil belajar yang baik. Salah satu pendekatan yang digunakan untuk mengembangkan lintasan belajar adalah pendekatan pendidikan matematika realistik.

Pendekatan Pendidikan Matematika Realistik (PMR) merupakan solusi yang dapat digunakan untuk meningkatkan pemahaman siswa dalam pembelajaran matematika (R.K.Sembiring, 2010:11-16). Pada PMR, pembelajaran dengan pendekatan ini lebih luas (kompleks) dan konsep-konsepnya bermakna dibanding dengan pendekatan lainnya. Siswa diperlakukan sebagai partisipan yang aktif dalam pembelajaran sehingga mereka dapat mengembangkan ide-ide matematika. Sedangkan guru hanya berperan sebagai fasilitator dalam pembelajaran. Melalui pendekatan PMR maka materi pelajaran yang disajikan selalu dihubungkan dengan kehidupan. PMR mendorong siswa untuk dapat membawa matematika pada pengajaran bermakna dengan mengkaitkannya dalam kehidupan sehari-hari yang bersifat realistik. Siswa diberikan masalah-masalah realistik, yaitu masalah-masalah yang berkaitan dengan situasi yang ada dalam kehidupan sehari-hari siswa.

Ada tiga prinsip utama dalam pembelajaran dengan menggunakan pendekatan PMR, yaitu: Guided Reinvention and Progressive Mathematizing, Didactical Phenomenology, dan Self Developed Models. Guided reinvention, prinsip ini menekankan "penemuan kembali" secara terbimbing. Melalui topiktopik tertentu yang disajikan, siswa diberi kesempatan sama untuk membangun dan menemukan kembali ide-ide dan konsep-konsep matematika. Setiap siswa diberi kesempatan sama untuk merasakan situasi dan mengalami masalah kontekstual yang memiliki berbagai kemungkinan solusi.

Bila diperlukan dapat diberikan bimbingan yang diperlukan. Jadi pembelajaran tidak diawali dari "sifat" atau "definisi" atau "teorema" atau "aturan" dan diikuti dengan "contoh-contoh" serta "penerapannya", tetapi justru dimulai dengan masalah kontekstual atau real/nyata meski hanya dengan membayangkannya, dan selanjutnya melalui aktivitas siswa diharapkan dapat menemukan kembali sifat, definisi dan lainnya itu.

Hal ini menunjukkan kesesuiannya dengan paham konstruktivisme yang meyakini bahwa pengetahuan tidak dapat ditransfer dari seseorang kepada orang lain tanpa aktivitas yang dilakukan sendiri oleh orang yang akan mengetahui pengetahuan tersebut.

Kedua, Progressive mathematization atau matematisasi progresif. Prinsip ini menekankan "matematisasi" atau "pematematikaan" yang dapat diartikan 
sebagai "upaya untuk mengarahkan kepada pemikiran matematika". Dikatakan progresif karena terdapat dua langkah matematisasi itu, yaitu matematisasi horisontal dan vertikal.yang berawal dari masalah kontekstual yang diberikan dan akan berakhir pada matematika yang formal.

Prinsip ini menekankan fenomena pembelajaran yang bersifat mendidik dan menekankan pentingnya masalah kontekstual untuk memperkenalkan topiktopik matematika kepada siswa. Menurut prinsip fenomena didaktik, situasi yang menjadi topik matematika diaplikasikan untuk diselidiki berdasarkan dua alasan: (1) memunculkan ragam aplikasi yang harus diantisipasi dalam pembelajaran dan (2) mempertimbangkan kesesuaian situasi dari topik sebagai hal yang berpengaruh untuk proses pembelajaran yang bergerak dari masalah nyata ke matematika formal.

Prinsip ketiga ini menunjukkan adanya fungsi “jembatan” yang berupa model. Karena berpangkal dari masalah kontekstual dan akan menuju ke matematika formal serta adanya kebebasan pada anak maka tidaklah mustahil siswa akan mengembangkan model sendiri. Model itu mungkin masih sederhana dan masih mirip dengan masalah kontekstualnya. Model ini disebut "model of" dan sifatnya masih dapat disebut "matematika informal".

Selanjutnya mungkin melalui generalisasi ataupun formalisasi dapat mengembangkan model yang mengarahkan ke matematika formal, model ini dapat disebut "model for". Hal tersebut sesuai dengan matematisasi horisontal dan matematisasi vertikal, yang memungkinkan siswa dapat menyelesaikan masalah tersebut dengan caranya sendiri (Soedjadi, 2007:4-5).

Hasil penelitian Rangkuti menyebutkan bahwa pendekatan pendidikan matematika realistic dapat meningkatkan hasisl belajar, dapat mengembangkan kreativitas, pemecahan masalah, dan motivasi belajar siswa (Ahmad Nizar Rangkuti, 2015:13-16). Selain itu Harahap menyebutkan bahwa pendekatan pendidikan matematika realistik dapat meningkatkan kemampuan komunikasi matematis siswa (Harahap, 2014). Selanjutnya Lede \& Yuliana menyebutkan bahwa learning trajectory yang disusun memberi kesempatan kepada siswa dalam menemukan model matematika dan siswa berhasil menemukan sendiri model tersebut dengan bantuan guru (Lede, 2018:406).

Dengan demikian learning trajectory menggunakan pendekatan matematika realistik (PMR) dapat membantu siswa mengaitkan materi teorema phytagoras dalam lingkungan nyata yang pernah dialaminya, seperti sebuah tangga yang disandarkan kedinding, dengan mengamati akan mengamati kolaborasi anatara tangga dan dinding. Dari peristiwa tersebut akan terbentuk segitiga siku-siku, kemudian siswa akan menentukan mana sisi miring, sisi tegak dan garis hipotenusa (sisi miring) serta luas segitiga yang terbentuk. Siswa juga dapat membangun pengetahuannya sendiri tanpa harus dijelaskan oleh gurunya. . 
Dengan adanya pengalaman nyata yang dilakukan oleh siswa dalam proses pembelajaran, maka diharapkan siswa lebih mudah mengingat dan memahami konsep teorema pythagoras sehingga memperoleh hasil belajar yang baik.

Berdasarkan latar belakang masalah di atas, maka artikel ini mendeskripsikan validitas dan praktikalitas lintasan belajar pokok bahasan Teorema Pythagoras dengan menggunakan Pendekatan Matematika Realistik di SMP Negeri 1 Hulu Sihapas Kabupaten Padang Lawas Utara.

\section{METODE PENELITIAN}

Penelitian ini merupakan jenis penelitian dan pengembangan atau Research and Development (R\&D). Pengembangan adalah metode penelitian yang digunakan untuk menghasilkan produk tertentu, atau menyempurnakan produk yang sudah ada ( Ahmad Nizar Rangkuti, 2016: 237).

Menurut Gravemeijer dan Van Erde, design research merupakan suatu metode penelitian yang bertujuan mengembangkan Local Inxtruction Theory (LIT) dengan kerjasama antara peneliti dan tenaga pendidik untuk meningkatkan kualitas pembelajaran (Prahmana, 2017). Dalam penelitian ini, model yang digunakan adalah model Gravemeijer \& Cobb.

Menurut Gravemeijer \& Cobb design research terdiri dari tiga fase, yakni: preliminary design, experiment, dan retrospective analysis. Secara diagram, alur penelitian tiap siklusnya menggunakan metode design research seperti terlihat pada gambar berikut (Ahmad Nizar Rangkuti, 2016: 241).

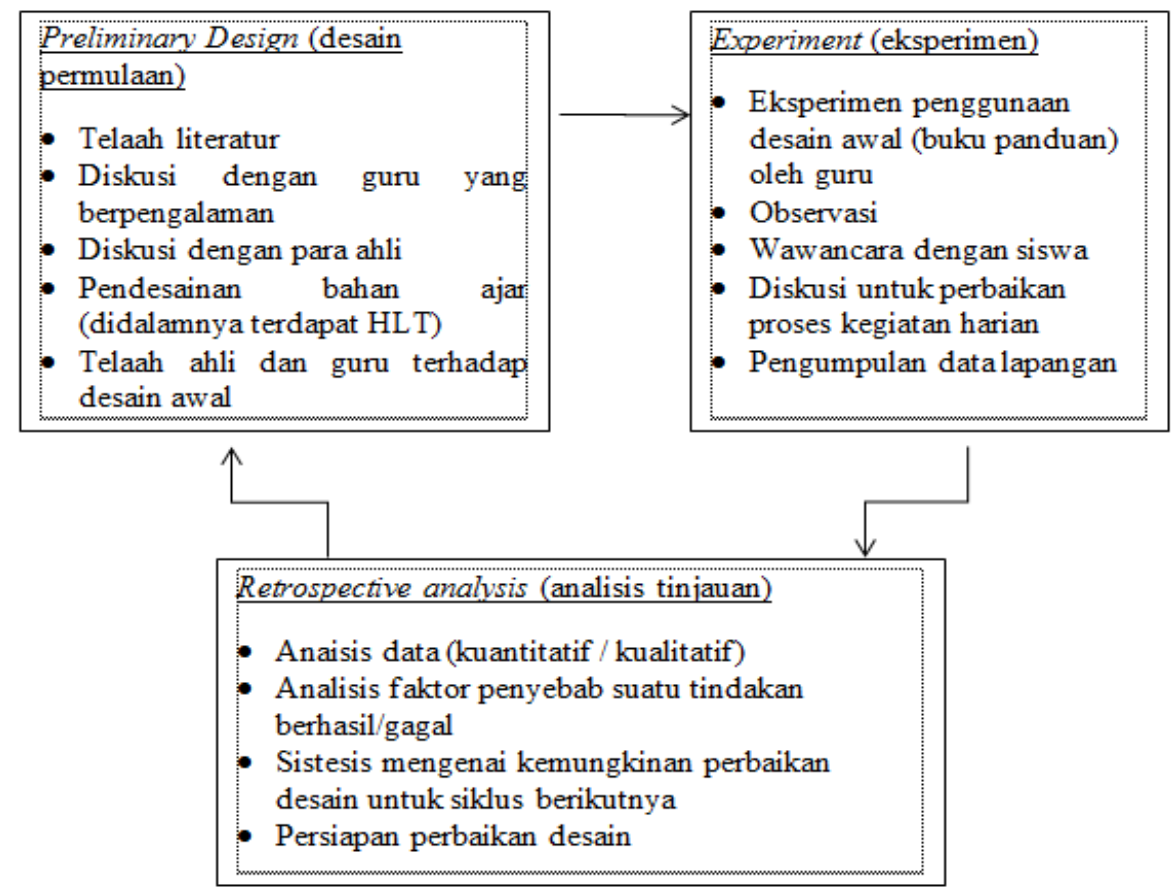

Gambar 1. Diagram Alur Design Research 


\section{Pada Tahap I: Preliminary Design (desain Pendahuluan)}

Pada fase ini, dibuat hypothetical learning trajectory (HLT). Dalam hal ini, HLT yang dibuat merupakan prediksi yang mungkin terjadi, baik proses berpikir siswa yang akan mendapat pembelajaran maupun hal-hal yang akan terjadi dalam proses pembelajaran. Untuk membuat HLT, terlebih dahulu dilakukan telaah literatur yang relevan, diskusi dengan guru yang berpengalaman dan diskusi dengan ahli (Rangkuti, 2016). Tujuan utama dari tahap ini adalah untuk mengembangkan urutan aktivitas pembelajaran dan mendesain instrumen untuk mengevaluasi proses pembelajaran tersebut (Prahmana, 2017).

Menurut Simon dan Bakker yang dikutip oleh Rangkuti, bahwa HLT terdiri atas tiga komponen utama yaitu: tujuan pembelajaran, sekumpulan aktivitas pembelajaran untuk mencapai tujuan-tujuan tersebut dan hipotesis tentang bagaimana siswa belajar dan bagaimana siswa berpikir. Pada fase pertama, HLT berfungsi sebagai petunjuk dalam mendesain panduan pembelajaran agar terfokus dalam hal ini bagaimana menyampaikan materi ajar, petunjuk bagaimana proses pembelajaran dan petunjuk dalam melakukan wawancara baik dengan guru, siswa maupun pihak-pihak yang terlibat dalam penelitian (Rangkuti, 2016).

\section{Pada Tahap II: Design Experiment (percobaan desain)}

Pada fase ini, desain yang sudah dirancang diuji cobakan di lapangan (di ruang-ruang kelas). Uji coba ini bertujuan untuk melihat apakah hal-hal yang sudah diprediksi pada fase preliminary design sesuai atau tidak dengan kenyataan yang terjadi. Pengalaman-pengalaman yang terjadi pada fase ini akan menjadi dasar dalam pendesainan ulang atau modifikasi HLT untuk proses pembelajaran berikutnya (Rangkuti, 2016). Uji coba ini bertujuan untuk mengeksplorasi dan menduga strategi dan pemikiran siswa selama proses pembelajaran yang sebenarnya.

\section{Pada Tahap III: Retrospective Analysis (analisis Retrospektif)}

Pada fase ini, semua data yang diperoleh pada fase eksperimen dianalisis. Proses analisisnya berupa perbandingan antara HLT yang diantisipasi sebelum pembelajaran dan aktivitas yang benar-benar terjadi dan dilanjutkan dengan analisis kemungkinan penyebab dan sintesa mengenai kemungkinan yang akan dapat dilakukan untuk memperbaiki HLT yang digunakan pada siklus berikutnya (Rangkuti, 2016). 


\section{HASIL DAN PEMBAHASAN}

\section{Hasil Penelitian}

Kegiatan dalam penelitian ini telah berhasil mengembangkan alur pembelajaran berbasis realistic yang valid dan praktis. Tahapn dalam penelitian ini dalam penelitian ini dilakukan dalam beberapa langkah pengembangan.

\section{a. Preliminary Design}

Pada tahap ini, peneliti mengimplementasikan ide awal tentang pengertian dari dalil teorema Pythagoras, membuktikan teorema Pythagoras, menentukan jenis-jenis segitiga, menerapkan dalil teorema Pythagoras kedalam soal dan menentukan triple pythagoras dengan cara mengkaji literatur (kajian pustaka), melakukan analisis terhadap kebutuhan siswa, melakukan observasi ke SMP Negeri 1 Hulu Sihapas mengenai kelayakan konteks yang akan digunakan dan diakhiri dengan pendesainan hypothetical learning trajectory (HLT). Adapun prosedur yang dilalui pada tahap ini yaitu:

1. Studi Pendahuluan

a) Kajian Pustaka

Pada tahap ini, peneliti melakukan analisis terhadap kurikulum yang berlaku untuk kelas VIII di SMP Negeri 1 Hulu Sihapas. Analisis tersebut meliputi penentuan kompetensi dasar, indikator serta tujuan pembelajaran yang dilalui dengan berbagai aktivitas dalam lintasan belajar melalui pendekatan realistik.

b) Analisis kebutuhan

Analisis kebutuhan ini dilakukan pada kelas IX-A yang berjumlah 23 siswa. Tahap ini bertujuan untuk melihat gambaran tentang kondisi siswa saat proses pembelajaran matematika sewaktu di kelas VIII.

Setelah dilakukan studi awal dengan pemberian tes untuk mengetahui kemampuan matematika siswa materi teorema Pythagoras, ditemukan beberapa hambatan yang dihadapi siswa. Diantaranya yaitu siswa tidak mampu memahami konsep teorema Pythagoras dengan baik karena hanya mengandalkan hapalan tanpa memahami konsep dari materi tersebut, sehingga mengalami kesulitan ketika menyelesaikan soal. Siswa tidak memahami perintah soal dengan jelas, serta siswa tidak bisa mengubah soal kedalam simbol matematika. Siswa juga kurang terbiasa untuk mengemukakan dan mengkonstruk ide-idenya, sehingga siswa hanya mengacu pada satu cara dalam menyelesaikan permasalahan.

c) Studi Kelayakan

Berdasarkan hasil observasi yang dilakukan di SMP Negeri 1 Hulu Sihapas Kabupaten Padang Lawas Utara terhadap ketersediaan alat dan 
bahan desain, maka hypothetical learning trajectory (HLT) layak untuk diterapkan.

2. Data Spesifikasi Produk

Spesifikasi produk yang dihasilkan berupa lintasan belajar berbasis realistik pokok bahasan teorema Pythagoras. Lintasan belajar didesain melalui hypothetical learning trajectory (HLT) yang dirancang sebagai berikut.

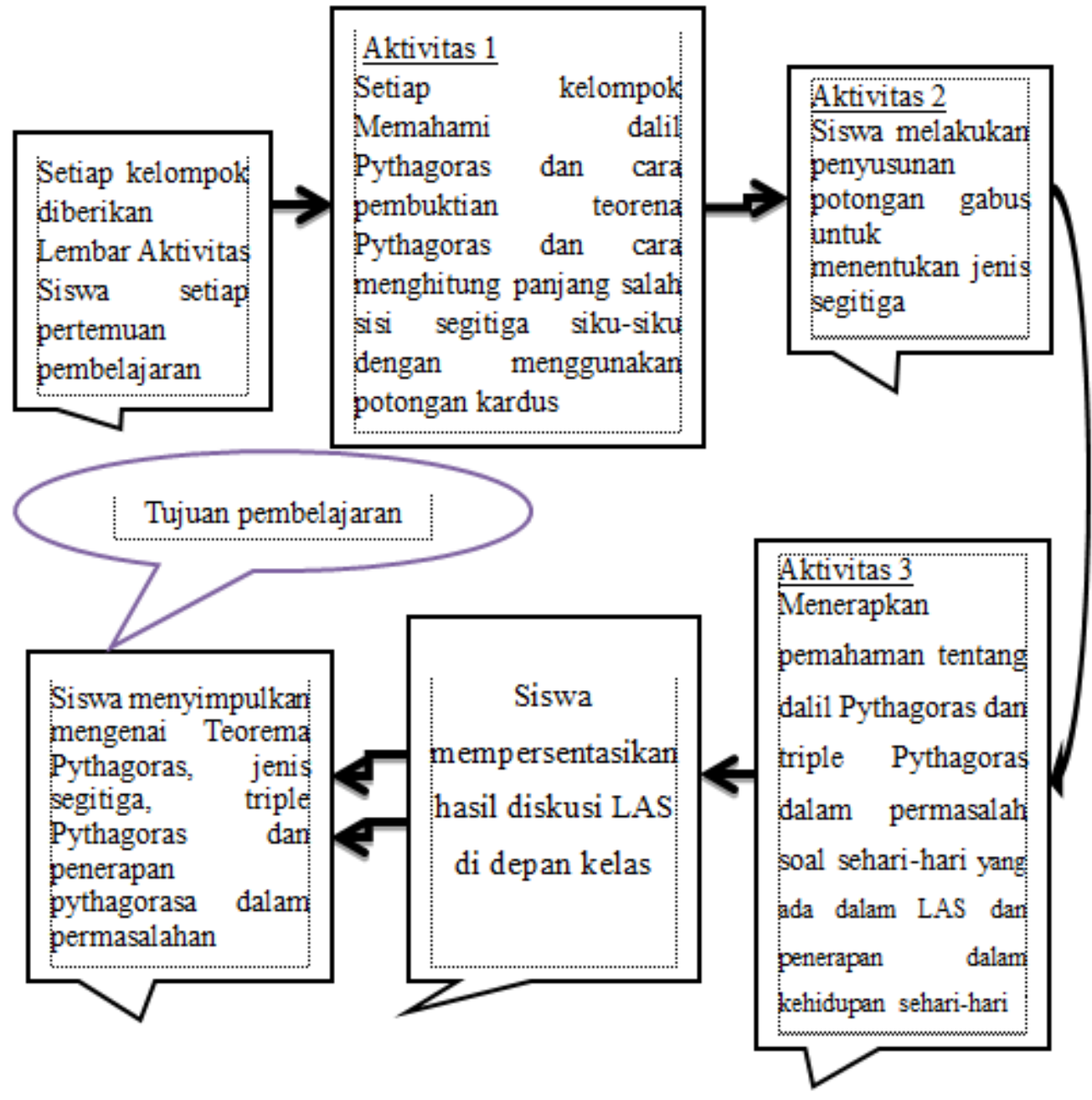

Gambar 2. Lintasan Belajar untuk Pembelajaran Teorema Pythagoras

Sekumpulan aktivitas dalam pembelajaran segitiga didesain berdasarkan lintasan belajar dan proses berpikir siswa yang dihipotesiskan. Himpunan aktivitas instruksi ini dibagi dalam 3 (tiga) aktivitas yang diselesaikan dalam 3 (tiga) kali pertemuan, mulai dari memahami konsep himpunan, memahami cara menentukan panjang salah satu sisi segitiga siku-siku dan jenis-jenis segitiga, memahami triple Pythagoras dan memahami penerepan Pythagoras dalam pemecahan masalah kehidupan sehari-hari siswa. 
3. Pengembangan Produk

Tahap pengembangan bertujuan untuk menghasilkan lintasan belajar pokok bahasan himpunan melalui pendekatan realistik yang valid dan praktis. Tahap pengembangan yang dimaksud meliputi:

a) Desain Pengembangan Produk Awal

Hypothetical learning trajectory (HLT) yang dirancang memuat tujuan aktivitas, deskripsi aktivitas dan dugaan pemikiran siswa yang mengacu pada indikator pencapaian yang telah ditentukan. Untuk tiap bagian dari HLT, dirancang aktivitas menyelesaikan permasalahan matematika yang realistik atau yang berhubungan dengan kehidupan sehari-hari.

b) Validasi Produk

Setelah merevisi rancangan hypothetical learning trajectory (HLT) pokok bahasan teorema Pythagoras, maka selanjutnya peneliti menuliskan desain tersebut ke dalam bentuk Lembar Aktivitas Siswa (LAS). Kemudian divalidkan oleh 3 orang validator, yaitu Suparni, S. Si,. M. Pd, Dwi Putria Nasution, M.Pd dan Sofiah Hasibuan, S.Pd. Berikut diuraikan hasil validasi dari ketiga validator.

Tabel 1. Hasil Validasi Lintasan Belajar melalui Pendekatan Realistik

\begin{tabular}{clccc}
\hline No & Aspek yang Dinilai & Rata-rata & Persentase & Kategori \\
\hline 1. & Kelayakan Isi & 0,85 & $85 \%$ & Sangat Valid \\
\hline 2. & Kelayakan Penyajian & 0,83 & $83 \%$ & Sangat Valid \\
\hline 3. & Kebahasaan & 0,89 & $89 \%$ & Sangat Valid \\
\hline 4. & $\begin{array}{l}\text { Pendidikan } \\
\text { matematika realistic }\end{array}$ & 0,86 & $86 \%$ & Sangat Valid \\
\hline Rata-rata Keseluruhan & $\mathbf{0 , 8 5}$ & $\mathbf{8 5 \%}$ & $\begin{array}{c}\text { Sangat } \\
\text { Valid }\end{array}$ \\
\hline
\end{tabular}

Berdasarkan hasil perhitungan validasi dari 2 dosen ahli bidang Matematika dan 1 guru matematika terhadap lintasan belajar pada tabel di atas. Komponen-komponen atau aspek-aspek dalam lintasan belajar mendapat penilaian sangat valid dengan perhitungan nilai rata-rata seluruh validator adalah 0,85. Dapat disimpulkan bahwa lintasan belajar melalui pendekatan kontekstual yang dikembangkan memenuhi kriteria kevalidan dengan kategori valid. Jadi, dapat disimpulkan bahwa lintasan belajar melalui pendekatan realistik ini telah valid dan layak untuk di ujicobakan pada tahap teaching experiment. 


\section{b. Design Experiment (Percobaan Desain)}

Pada tahap ini, peneliti mengujicobakan desain hypothetical learning trajectory (HLT) yang telah dinyatakan valid. Ujicoba ini bertujuan untuk mengeksplorasi dan menduga strategi dan pemikiran siswa selama proses pembelajaran yang sebenarnya. Ujicoba desain hypothetical learning trajectory (HLT) ini dilaksanakan melalui 3 aktivitas yang termuat dalam 3 kali pertemuan. Selama ujicoba, kegiatan pembelajaran diobservasi oleh dua observer yaitu Sofiah Hasibuan, S.Pd selaku guru matematika di SMP Negeri 1 Hulu Sihapas dan Syarifah Nur Akmal Harahap selaku teman sejawat. Observer bertugas mengamati pelaksanaan pembelajaran yang menggunakan desain hypothetical learning trajectory (HLT) berdasarkan lembar observasi yang telah disediakan. Berikut deskripsi pelaksanaan pembelajaran menggunakan desain hypothetical learning trajectory (HLT) berbasis realistik.

\section{c. Analysis Retrospective}

Pada tahapan ini, peneliti melakukan analisis terhadap proses pembelajaran pada tahap teaching experiment (percobaan desain). Proses analisis data dilakukan dengan membandingkan hasil pengamatan selama proses pembelajaran dengan hypothetical learning trajectory (HLT) yang telah didesain pada tahap preliminary design.

\section{Pembahasan}

\section{Validitas HLT (Hypothetical Learning Trajectory)}

Hypothetical Learning Trajectory melalui pendekatan pendidikan matematika realistik pokok bahasan teorema Pythagoras dinyatakan valid oleh validator dan melalui presentasi validasi yang memuat beberapa aspek yang diamati, yaitu aspek kelayakan isi, kelayakan penyajian, kebahasaan dan pendidikan matematika realistik. Berarti isi dari desain yang ada dalam hypothetical learning trajectory (HLT) sudah valid dan lengkap menurut validator.

Pada aspek kelayakan isi diperoleh nilai validitas 0,85 $=85 \%$ dengan kategori sangat valid. Hal ini dilihat dari butir penilaian yang mencakup kelengkapan learning trajectory, keluasan learning trajectory, keakuratan fakta dan data, menggunakan contoh kasus yang terdapat dalam kehidupan sehari-hari dan mendorong rasa ingin tahu. Berdasarkan butir penilaian diperoleh kelayakan isi dalam HLT sudah sesuai dengan aturan pada desain.

Pada aspek kelayakan penyajian diperoleh nilai validitas $0,83=83 \%$ dengan kategori sangat valid. Hal ini dilihat dari butir penilaian yang mencakup keterlibatan siswa, keterkaitan antar kegiatan belajar dan keutuhan makna dalam kegiatan belajar. Berdasarkan butir penilaian diperoleh kelayakan isi dalam HLT valid sesuai dengan aturan penyajian pada desain. 
Pada aspek kebahasaan diperoleh nilai validitas $0,89=89 \%$ dengan kategori sangat valid. Hal ini dilihat dari butir penilaian yang mencakup keefektifan kalimat, pemahaman konsep terhadap pesan atau informasi dan kesesuaian dengan intelektual siswa. Hal ini berarti penggunaan bahasa yang terdapat pada HLT dapat dikatakan cukup baik dan mudah dimengerti.

Pada aspek pendidikan matematika realistik memperoleh nilai 0,86 dengan kategori sangat valid Hal ini dilihat dari butir penilaian yang mencakup keterkaitan antara materi yang diajarkan dengan situasi dunia nyata siswa, kemampuan mendorong siswa membuat hubungan antara pengetahuan yang dimiliki siswa dengan penerapannya dalam kehidupan sehari-hari, memahami masalah, menjelaskan masalah, menyelesaikan masalah, membandingkan dan mendiskusikan jawaban dan menyimpulkan. Berarti, setiap aktivitas dalam hypothetical learning trajectory (HLT) sudah sesuai dengan komponen pendidikan matematika realistik.

Berdasarkan kategori-kategori validitas tersebut secara keseluruhan nilai rata-rata yang diperoleh $85 \%$ berada pada rentang $81 \%$ sampai $100 \%$ dengan kategori sangat valid. Hal tersebut menunjukkan bahwa HLT melalui pendekatan realistik pokok bahasan teorema Pythagoras ini menurut para ahli sudah dinyatakan baik dan dapat digunakan dalam proses pembelajaran.

\section{Praktikalitas HLT (Hypothetical Learning Trajectory)}

Desain yang baik harus bersifat praktis. Kriteria ini dipakai untuk menilai praktikalitas dalam pengembangan desain ini adalah keterkaitan siswa pada aktivitas pembelajaran, materi yang disampaikan, kemudahan bahasa yang digunakan dan motivasi siswa dalam pembelajaran.

Pelaksanaan pembelajaran dengan menggunakan HLT melalui pendekatan realistik, menunjukkan bahwa proses pembelajaran dapat menciptakan dengan baik situasi kelas yang mendorong siswa untuk saling bertanya, menjawab dan mengeluarkan pendapat dan terjadinya interaksi antarsiswa. Hal ini terlihat dari bagaimana siswa menyelesaikan soal-soal yang diberikan pada Lembar Aktivitas Siswa (LAS) dan dokumentasi-dokumentasi yang diambil ketika proses belajar dan pembelajaran berlangsung.

Selama pelaksanaan pembelajaran dengan menggunakan desain HLT melalui pendekatan realistik, secara umum waktu yang disediakan sudah cukup. Penggunaan desain dapat memudahkan siswa memahami pelajaran dan menyelesaikan masalah yang berkaitan dengan kehidupan mereka sehari-hari. Karena siswa sudah bisa menemukan konsep berdasarkan LAS yang mereka kerjakan, sehingga siswa dapat memahami materi pelajaran dengan baik.

Hasil praktikalitas desain belajar dengan menggunakan pendekatan realistic sebagai berikut: 
Tabel 2. Hasil Praktikalitas Desain Belajar dengan Menggunakan Pendekatan Realistic

\begin{tabular}{clccc}
\hline No. & Aspek yang Dinilai & Rata-rata & Persentase & Kategori \\
\hline 1 & Ketertarikan & 0,86 & $86 \%$ & Sangat Praktis \\
\hline 2 & Materi & 0,79 & $79 \%$ & Praktis \\
\hline 3 & Bahasa & 0,89 & $89 \%$ & Sangat Praktis \\
\hline 4 & Motivasi & 0,86 & $86 \%$ & Sangat Praktis \\
\hline Rata-rata Keseluruhan & $\mathbf{0 , 8 5}$ & $\mathbf{8 5 \%}$ & Sangat Praktis \\
\hline
\end{tabular}

Berdasarkan angket respon siswa terhadap pembelajaran dengan menggunakan HLT melalui pendekatan realistik termasuk kategori sangat praktis. Untuk aspek ketertarikan siswa pada aktivitas pembelajaran memiliki persentase $86 \%$ atau 0.86 dengan kategori praktis, materi yang disampaikan 0,79 $=79 \%$ dengan kategori praktis, aspek bahasa $0,89=89 \%$ dengan kategori sangat praktis, dan motivasi yang diberikan $0,86=86 \%$ dengan kategori sangat praktis. Secara keseluruhan rata-rata nilai hypothetical learning trajectory (HLT) memiliki nilai persentase $85,4 \%$ atau 0,85 dengan kategori sangat praktis. Hal tersebut menandakan bahwa desain hypothetical learning trajectory (HLT) melalui pendekatan pendidikan matematika realistik telah praktis digunakan.

\section{KESIMPULAN}

Penelitian ini merupakan design research atau penelitian pengembangan tipe validation study yang menghasilkan sebuah produk, yaitu produk lintasan belajar (learning trajectory) siswa dalam pembelajaran teorema Pythagoras melalui pendekatan realistik. Learning trajectory yang dirancang oleh peneliti memanfaatkan bahan ataupun media yang mudah ditemukan dalam kehidupan sehari-hari yaitu potongan kardus, dimana siswa beraktifitas menyusun potongan kardus sesuai dengan gambar pada LAS dengan arahan guru sehingga dapat membuktikan dalil dari Pythagoras dan dapat memahmi dari dalil tersebut. Learning trajectory ditemukan peneliti melalui perangkat pembelajaran sebagai pendukung tercapainya tujuan pembelajaran. Perangkat pendukung tersebut berupa RPP dan LAS (Lembar Aktivitas Siswa) yang disusun berdasarkan komponen-komponen yang terdapat pada pendekatan realistik.

Berdasarkan proses dan hasil penelitian, diperoleh kesimpulan bahwa Lintasan belajar melalui pendekatan realistik yang dikembangkan sudah valid, baik dari aspek kelayakan isi, penyajian, kebahasaan maupun kontekstual dengan nilai $85 \%$. Hal ini diperoleh dari pendapat para ahli yang menyatakan Learning trajectory melalui pendekatan kontekstual dikategorikan baik dan dapat digunakan dalam proses pembelajaran. Para ahli tersebut terdiri dari 2 dosen dan 1 guru matematika yang mengajar di SMP Negeri 1 Hulu Sihapas Kabupaten 
Padang Lawas Utara. Dan Lintasan belajar melalui pendekatan realistik yang dikembangkan sudah memenuhi kriteria praktis baik dari aspek ketertarikan, materi, bahasa dan motivasi dengan nilai $85,44 \%$. Hal ini dapat dilihat dari data angket respon siswa dan observasi terhadap pelaksanaan pembelajaran.

\section{DAFTAR PUSTAKA}

Harahap, I. F. (2014). Peningkatan Kemampuan Komunikasi Matematika Melalui Pendekatan Realistic Mathematic Education (RME) pada Materi Pecahan Siswa Kelas IV SDN 200404 Pintulangit. IAIN Padangsidimpuan.

Lede, Y. K. \& Y. I. K. (2018). Lintasan Belajar untuk Membelajarkan Materi Membuat Model Matematika Sistem Persamaan Linear Dua Variabel Bagi Siswa Kelas VIII. In Prosiding Semminar Nasional Pendidikan Matematika Etnomatnesia (pp. 406-415). Yogyakarta.

Prahmana, R. C. I. (2017). Design Research: Teori dan Implementasinya: Suatu Pengantar. Depok: Rajawali Pers.

R.K.Sembiring. (2010). Pendidikan Matematika Realistik Indonesia (PMRI):perkembangan dan tantangannya. Indo Ms.J.M.E, 1(1), 11-16.

Rangkuti, A. N. (2015). Developing a Learning Trajectory on Fraction Topics by Using Realistic Mathematics Education Approach in Primary School. IOSR. Journal of Research \& Method In Education, 5(5), 13-16.

Rangkuti, A. N. (2016). Metode Penelitian Pendidikan Pendekatan Kuantitafi, Kualitatif, PTK, dan Penelitian Pengembangan. Bandung: Citaputaka Media.

Slavin, R. E. (2008). Psikologi Pendidikan: Teori dan Praktik. Jakarta: Indeks.

Soedjadi, R. (2007). Inti Dasar-dasar Pendidikan Matematika Realistik Indonesia. Jurnal Pendidikan Matematika, 1(2), 4-5.

Suherman, E. (2003). Strategi Pembelajaran Matematika Kontemporer. Bandung: JICA UPI.

Sumarto, \& Novilia, S. (2013). Design Research On Mathematics Education: Ratio Table In Developing The Stulmdents. Jurnal Proportional Reasoning, 7(1), 69-80.

Syahroma, D. (2014). Pengaruh Penerapan Learning Cycle 5E Terhadap Pemahaman Konsep Dan Kemampuan Komunikasi Matematika Pada Materi Pokok Program Linear Siswa Kelas X SMKN1 Angkola Timur. IAIN Padangsidimpuan. 